\title{
Substrate composition and dimensionality direct osteocyte gene expression
}

\author{
Amenah Dhannoon*, Robert Thomas Brady, Fergal O'Brien \\ From 4th International Conference for Healthcare and Medical Students (ICHAMS) 2014 \\ Dublin, Ireland. 24-25 October 2014
}

\section{Background}

Osteoporosis has become a major public health problem, it is characterised by loss of bone mass and architecture due to disturbance in bone remodelling. Most current treatments retard bone loss but have no stimulating effect on bone formation [1]. Osteocytes act as an orchestrator for bone modelling, and secrete the glycoprotein sclerostin which negatively regulates bone formation and is a potential novel drug target [2]. Due to difficulty of accessing and studying osteocytes in vitro, an osteocyte-like MLO-Y4 cell line was developed. However, these cells only secrete sclerostin in trace amounts [3]. The objective of this study was to develop a novel biomimetic environment that would stimulate MLO-Y4 to express the osteocyte specific Sost gene.

\section{Methods}

Four different compositions were seeded with MLO-Y4 cells and accommodated in two different cultures (3D scaffolds versus 2D films). After 5 days of culture, Sost gene expression was analysed using Real-time PCR in all groups and the data was normalised to a housekeeping gene (18s).

\section{Results}

There was a robust statistically significant increase in MLO-Y4 gene expression for Sost when cultured on a Collagen-Hydroxyapatite (HA) substrate compared to a Collagen-only substrate. Furthermore, the 3D dimensionality enhanced gene expression across all different compositions.

\section{Conclusions}

This study has demonstrated that scaffold composition and dimensionality has a significant influence upon

Royal College of Surgeons in Ireland, Dublin, Ireland regulation of MLO-Y4 gene expression. This also indicates that Sost gene is regulated by both composition and dimensionality. The ability to stimulate MLO-Y4 cell line to express Sost sufficiently will offer a precious tool for researchers to further study sclerostin secretion, identify novel regulators of Sost gene expression and investigate them to develop new therapeutic agents that may offer advantage over the currently available treatments for osteoporosis.

Published: 27 October 2015

\section{References}

1. Moester MJC, Papapoulos SE, Löwik CWGM, van Bezooijen RL: Sclerostin: current knowledge and future perspectives. Calcif Tissue Int 2010, 87(2):99-107.

2. Bonewald LF: The amazing osteocyte. J Bone Miner Res 2011, 26(2):229-38.

3. Kato Y, Windle JJ, Koop BA, Mundy GR, Bonewald LF: Establishment of an osteocyte-like cell line, MLO-Y4. J Bone Miner Res 1997, 12(12):2014-23.

\section{doi:10.1186/1753-6561-9-S7-A6}

Cite this article as: Dhannoon et al:: Substrate composition and dimensionality direct osteocyte gene expression. BMC Proceedings 2015 9(Suppl 7):A6.
() Biomed Central

(c) 2015 Dhannoon et al. This is an Open Access article distributed under the terms of the Creative Commons Attribution License (http://creativecommons.org/licenses/by/4.0), which permits unrestricted use, distribution, and reproduction in any medium, provided the original work is properly cited. The Creative Commons Public Domain Dedication waiver (http://creativecommons.org/ publicdomain/zero/1.0/) applies to the data made available in this article, unless otherwise stated.
Submit your next manuscript to BioMed Central and take full advantage of:

- Convenient online submission

- Thorough peer review

- No space constraints or color figure charges

- Immediate publication on acceptance

- Inclusion in PubMed, CAS, Scopus and Google Scholar

- Research which is freely available for redistribution 